\title{
Frequently Asked Questions about Landscape Fertilization for Florida-Friendly Landscaping Ordinances $^{1}$
}

Sartain, J.B., L.T. Trenholm, E.F. Gilman, T.A. Obreza, and G. Toor²

These days, water quality and quantity are important issues that are on everyone's mind. These Frequently Asked Questions address common concerns related to irrigation, and fertilizer. These FAQs draw on extensive UF/IFAS research, and were created to help guide government officials in developing regulations based on science.

\section{How did UF/IFAS come up with its recommendations?}

\section{Lawn}

UF/IFAS' nitrogen fertilizer recommendations are based on many years of research on different turfgrass species and regions of the state where they are grown. Turfgrass color, density, and leaf $\mathrm{N}$ concentrations were used as a basis for determining when additional $\mathrm{N}$ fertilization was required.

Phosphorus recommendations, as outlined in the current Urban Turfgrass Fertilizer Rule, are based on the quantity of $\mathrm{P}$ required to maintain a minimum tissue $\mathrm{P}$ concentration as determined by a standard soil test (Mehlich-1 P soil test level).

Potassium recommendations are based on Mehlich-1 soil test and required tissue $\mathrm{K}$ levels. (Dudeck et al.1982; Liu et al. 2006; Liu et al. 2008; Liu et al., 2008; Sartain, 1993; Sartain, 1996; Sartain, 2002; Sartain, 2007; Sartain, 2008; Sartain, 2008; Trenholm \& Unruh, 2005; Trenholm \& Unruh, 2007).

\section{Landscape}

Tree and shrub recommendations are based on about 25 studies conducted over the last 70 years, some of which were conducted in Florida.

\section{What are the UF/IFAS fertilizer recommendations for turfgrasses in Florida?}

Specific recommendations for fertilization of turfgrasses in Florida relative to times of year, when to apply and specific nutrient sources and rates can be found in Sartain (2007).

1. This document is ENH1115, one of a series of the Environmental Horticulture Department, Florida Cooperative Extension Service, Institute of Food and Agricultural Sciences, University of Florida. Original publication date December 2008. Revised January 14, 2009. Visit the EDIS Web site at http://edis.ifas.ufl.edu.

2. J. B. Sartain, professor, Department of Soil and Water Science; L. T. Trenholm, associate professor; E. F. Gilman, professor, Department of Environmental Horticultural Sciences; T. A. Obreza, professor, Department of Soil and Water Science; G. Toor, assistant professor, Gulf Coast Reseach and Education Center - Balm; Institute of Food and Agricultural Sciences, University of Florida, Gainesville, FL 32611.

The Institute of Food and Agricultural Sciences (IFAS) is an Equal Opportunity Institution authorized to provide research, educational information and other services only to individuals and institutions that function with non-discrimination with respect to race, creed, color, religion, age, disability, sex, sexual orientation, marital status, national origin, political opinions or affiliations. U.S. Department of Agriculture, Cooperative Extension Service, University of Florida, IFAS, Florida A. \& M. University Cooperative Extension Program, and Boards of County Commissioners Cooperating. Millie Ferrer, Interim Dean 
Generalized N rates relative to turfgrass species and region of the state follow:

Table 1. Recommended fertilizer rates for various home lawn grass species.

\begin{tabular}{|c|c|}
\hline Species/Location & $\begin{array}{l}\text { Interim N } \\
\text { Recommen } \\
\text { dations } \\
(\text { lbs } 1000 \\
\left.\mathrm{ft}^{-2} \mathbf{y r}^{-1}\right)^{*} \text {, } \\
\text { ** }\end{array}$ \\
\hline Bahiagrass- North & $2-3$ \\
\hline Bahiagrass- Central & $2-4$ \\
\hline Bahiagrass- South & $2-4$ \\
\hline Bermudagrass- North & $3-5$ \\
\hline Bermudagrass- Central & $4-6$ \\
\hline Bermudagrass- South & $5-7$ \\
\hline Centipedegrass- North & $1-2$ \\
\hline Centipedegrass- Central & $2-3$ \\
\hline Centipedegrass- South & $2-3$ \\
\hline St. Augustinegrass- North & $2-4$ \\
\hline St. Augustinegrass- Central & $2-5$ \\
\hline St. Augustinegrass- South & $4-6$ \\
\hline Zoysiagrass- North & $3-5$ \\
\hline Zoysiagrass- Central & $3-6$ \\
\hline Zoysiagrass- South & 4-6 \\
\hline \multicolumn{2}{|c|}{$\begin{array}{l}{ }^{*} \text { Homeowner preferences for lawn quality } \\
\text { and maintenance level will vary, therefore a } \\
\text { range of fertility rates for each grass and } \\
\text { location are recommended. Additionally, } \\
\text { effects within a localized region (i.e., } \\
\text { micro-environmental influences such as } \\
\text { shade, drought, soil conditions, and } \\
\text { irrigation) will necessitate that a range of } \\
\text { fertility rates be used. } \\
\text { **These recommendations assume that } \\
\text { grass clippings are recycled. }\end{array}$} \\
\hline
\end{tabular}

\section{What is the best fertilizer for turfgrasses in Florida? Should different fertilizers be used in the spring, winter, or summer months?}

This answer varies depending on the use, water stress, and microclimate of the environment in which the grass is grown. In general, homeowners should use a fertilizer with some of the nitrogen in slow-release form. Fertilizer should not be applied during the winter in North Florida.

In the early spring, mixtures containing a higher percentage of soluble than slow-release fertilizer materials should be used, e.g., 70 percent water soluble and 30 percent slow-release. During the summer, a mixture containing a higher percentage of slow-release materials, e.g., 50 percent, should be used. A description of fertilizer materials used in lawn fertilization can be found in Sartain \& Kruse (2001).

\section{Are the current fertilizer recommendations based on environmental water quality protection?}

No. Research at UF/IFAS has traditionally been based on turfgrass quality. Current research is aimed at determining the impacts of fertilizer rate and management on the amount of fertilizer leaching through turfgrass. Research on non-compacted soils under normal conditions has shown that residential turfgrass can absorb at least 0.7 to $1.0 \mathrm{lbs}$ of applied soluble $\mathrm{N}$ and up to 0.25 . lbs phosphate per $1000 \mathrm{sq} \mathrm{ft}$ without negative environmental impact on subsurface water quality (Sartain, 2008; Liu et al., 2008).

Turfgrass is an excellent natural filter for nutrients provided rates do not exceed UF/IFAS recommendations. Fertilizer applied accidently to non-pervious surfaces (roads, sidewalks, driveways etc.) is likely to be washed in to stormwater and impact local water quality.

\section{Under what conditions is fertilizer leached or contained in runoff from turfgrass and landscaped areas?}

Leaching may occur when fertilizer is applied at rates that exceed UF/IFAS recommendations (Trenholm \& Unruh, 2007), or following heavy rainfall (ibid.; Erikson et al. 2001).

The only time $\mathrm{N}$ was detected in runoff from St. Augustine plots in South Florida was during an extreme rainfall event (a hurricane), and even then, 
the $\mathrm{N}$ concentration in the runoff was lower than the $\mathrm{N}$ concentration in the rain water (Erickson et al. 2001).

\section{Is the amount of fertilizer that may be leached or contained in runoff affected by rainfall amounts? If so, will a "blackout" of fertilizer use during the summer reduce leaching and runoff? Could there be any unintended consequences of a long (three- to four-month) blackout period?}

Heavy rainfall shortly after fertilization (prior to fertilizer being watered in properly) may cause increased leaching or runoff. However, the lack of nutrition during the active growing period of our warm-season grasses (summer) may cause loss of grass, increased weed infestation, soil erosion, and other problems that may increase runoff. Runoff was collected only under extreme hurricane conditions from St. Augustinegrass growing on a 10 percent slope in south Florida, and the concentration of $\mathrm{N}$ in the runoff water was reported to be lower than that in the natural rainfall (Erickson et al., 2001). During a grow-in of bermudagrass on a 10 percent slope, 0.03 percent of the applied $\mathrm{N}$ was collected in the runoff from plots irrigated at twice ET (Shaddox \& Sartain, 2000).

Whether banning fertilizer use in the summer will reduce leaching and runoff has not been fully addressed by research at the moment. A recent survey of St. Augustinegrass lawns in South Florida based on tissue $\mathrm{N}$ concentration suggests that the lawns that did not receive $\mathrm{N}$ fertilization during the "blackout" period had low levels of $\mathrm{N}$, which could lead to inferior turfgrass quality and reduce the ability of the turfgrass to filter applied nutrients. For this reason, UF/IFAS recommends fertilization during the summer months at recommended rates (one application of controlled-release fertilizer and iron) to maintain quality turfgrass. The low summer fertilization rates recommended by UF/IFAS help maintain healthy turf and minimize leaching, while keeping maintenance low.
Turfgrass roots are responsible for nutrient uptake. Research has shown that the root mass of turfgrass is limited in the early spring, reaches its maximum weight during the months of May, June, July, and August; begins to decline during September, October, and November; and is at its minimum during dormancy (Sartain, 2002). Turfgrass also accumulates its largest quantity of nutrients during its most active growing period, that is, during the months of May, June, and July (Sartain, 2008).

If turf is not fertilized during the summer months when the grass is most actively growing and the root system is at its maximum, the potential for declining health and nutrient leaching increases. One of the possible responses of the public, if a ban on summer fertilization were enacted, could be to apply additional fertilizer before summer to "carry" the turfgrass through the season, followed by application of more fertilizer in September to aid the turfgrass recovery. Extra fertilizer applied in the spring may result in additional nutrient leaching due to a higher rate of application and a smaller root mass. Additional fertilizer applied after the ban will result in more leaching due to the higher rate of fertilization and the reduction in root mass during the fall. Thus, banning fertilization during the summer most likely will result in more leaching due to application timing and rate and reduced root growth. Lack of summer fertilization may also result in unhealthy turfgrass, which has been shown to leach more nutrients than healthy turfgrass (Rosen et al., 2008).

\section{What is the recommended fertilizer-free area for protection of Florida water bodies?}

As recommended in the Green Industries BMP manual, the fertilizer-free zone for protection of water bodies is a minimum of either 3 or 10 feet, depending on soil type, slope, and type of fertilizer spreader. The minimum should be 3 feet when either a drop spreader, rotary spreader with deflector shield, or handheld hose sprayer is used. The minimum should be 10 feet when a rotary spreader without a deflector shield is used. 
These recommendations are not based on a specific scientific study but on best informed judgment and anecdotal evidence of sharp contrasts typically observed between fertilized and unfertilized turfgrass, suggesting that the applied fertilizer materials did not move freely down the slope. Thus, the chosen buffer zones appear safe and not prone to contribute to non-point source pollution (NPSP). Not fertilizing a wide strip may lead to a large area of unhealthy turf that can lead to increased soil erosion and increased NPSP.

\section{Are leaching and runoff different between quick- and slow-release fertilizers?}

The results of our research suggest two things: 1) St. Augustinegrass can accumulate $1 \mathrm{lb}$ of $\mathrm{N}$ per $1,000 \mathrm{sq} \mathrm{ft}$ without negative $\mathrm{N}$ leaching impact when IFAS recommendations are followed (Sartain, 2007), and 2) the form of $\mathrm{N}$ applied at the $1 \mathrm{lb}$ per $1,000 \mathrm{sq} \mathrm{ft}$ rate does not matter. Due to turf's ability to filter nutrients, if any fertilizer is applied at the correct rates and in the correct manner, neither will result in much leaching or runoff - the results will differ very little (Park, 2006).

\section{Does reclaimed water reduce the amount of fertilizer needed for Florida landscapes?}

Reclaimed water may contain plant nutrients, especially $\mathrm{N}$ and $\mathrm{P}$, which may need to be considered in any fertility program. It is not clear that all the nutrients in reclaimed water are available for plants. Over-application of, and high salt content in, reclaimed water may damage turfgrass roots. Applying too much reclaimed water may cause runoff and contamination of the local waterways.

Not all reclaimed water contains the same concentration of $\mathrm{N}$, and the analysis can vary daily. Thus, one should obtain a representative analysis of the reclaimed water and adjust the rate of applied fertilization based on the amount of reclaimed water used. The nutrient content of reclaimed water can also vary greatly depending on the processes used by a particular water reclamation facility. Water reclamation facilities, in general, have not yet begun to educate their customers about the nutrients they are receiving. UF/IFAS can play a role in educating the public on the "free" fertilizer in reclaimed water; however, some of the suppliers of reclaimed water have now started charging for it (Ruple et al., 1999).

One of the problems with reclaimed water is the salts that it contains. Under normal rainfall conditions, salt accumulation is not generally a problem in Florida, but it may become a problem with high use of reclaimed water. With prolonged use during drought conditions, salts may accumulate in the root zone, limiting root growth and water uptake (Harivandi, 1982).

\section{At what rate do grass clippings decompose and release nutrients back into the soil? Will returning clippings to the lawn reduce fertilizer requirements?}

Turfgrass clippings vary in composition of lignin and cellulose relative to species, which determines the rate of decomposition. In addition, soil temperature and microbial activity influence decomposition rate. Typically, bermudagrass and centipedegrass contain higher levels of lignin and cellulose than St. Augustinegrass (Sartain \& Volk, 1984).

In general, turfgrass clippings will almost completely decompose within two to four weeks, depending on the turfgrass species and the climatic conditions. The quantity of nutrients released back to the turfgrass depends on the nutrient concentration in the tissue and the growth rate of the turfgrass (Koop \& Guillard, 2002; Sartain, 1993; Sartain, 2004).

11. What scientific evidence is available to show that nitrogen added to the lawn is removed through denitrification? What percent of the applied nitrogen can be accounted for by turfgrass use and denitrification? What happens to the remainder of the fertilizer? 
Numerous research studies suggest the following about $\mathrm{N}$ applied to turfgrasses: 40 to 70 percent is taken up by plant, 5 to 10 percent is retained in the soil, and 0 to 25 percent is leached (Brown \& Sartain, 2003). Thus, the remainder ( 55 to 0 percent) either denitrifies or volatilizes. Some fertilizer materials are subject to loss of $\mathrm{N}$ through volatilization (Volk, 1956). Studies have suggested that as much as 30 to 70 percent of the applied $\mathrm{N}$ in urea can be lost through volatilization (Volk, 1961). Ammonia $\mathrm{N}$ can also be lost from surface application of ammonium source fertilizers applied to high $\mathrm{pH}$ soils. Denitrification estimates are rarely evaluated during turf fertilization, but could be substantial, especially in over-watered lawns. Ten to fourteen days after fertilization of turfgrass with any $\mathrm{N}$ source, the only $\mathrm{N}$ found in the thatch layer or leached was in the nitrate form (Sartain \& Gooding, 2000; Shaddox \& Sartain, 2001). If the lawn is maintained using excessive rates of irrigation, the highly active microbial population in the thatch layer could indeed transform the nitrate- $\mathrm{N}$ under waterlogged conditions to a volatile form of $\mathrm{N}$ that would be lost through volatilization.

Turfgrasses are fairly unique when it comes to $\mathrm{N}$ utilization; their ability to assimilate $\mathrm{N}$ is rarely exceeded. In the event that excess $\mathrm{N}$ exists, it may be readily assimilated by the microbial population, tied up by the soil organic matter, or leached by water moving through the soil profile.

\section{What is the nitrogen threshold that may compromise water quality standards in runoff?}

Limited research exists relative to runoff from Florida turfgrasses. Based on the current research data available, runoff from healthy turfgrass growing on a 10 percent slope was limited to an extreme hurricane event when excessive rainfall occurred (Erickson et al., 1999; Erickson et al., 2001). The water that was collected in the runoff from the turfgrass actually contained less $\mathrm{N}$ than did the rainfall.

It has also been reported that only 0.03 percent of the applied $\mathrm{N}$ was collected in an excessively irrigated bermudagrass during grow-in on a 10 percent slope (Shaddox \& Sartain, 2000). Thus, it appears based on these studies that very little if any nitrogen, when applied at IFAS-recommended rates, moves across the surface of a healthy turfgrass, and there is very little threat of water quality compromise as a result of runoff. Other potential sources of nitrogen found in waterways include pet feces and septic tanks in landscapes.

\section{Is it possible to distinguish between nitrogen sources (landscape fertilizers vs. septic tanks) through isotope indicators?}

Based on specific ratios of $\mathrm{N}$ isotopes, the probable origin of the $\mathrm{N}$ source can be identified within the limits of current technology. Isotope analysis gives good clues but not definitive answers (Havens, 2004).

\section{What role, if any, do native plants play in reducing fertilizer use in the landscape? Should urban landscapes be planted totally in native plants? Why or why not? What is the environmental value of turfgrass in the landscape? Is there a balance?}

A plant's indigenous status does not affect its fertilizer or irrigation requirements. There is no scientific evidence that native plants require less fertilizer and water than plants not native to Florida. To put it another way, residential and commercial landscapes are often very different from the native conditions where a plant originated, even if they are found in the same state. Additionally, a plant that was previously indigenous to a site may not be adapted to the location any longer, depending on the way the site has been altered. In a recent research study, Florida native shrubs required the same irrigation as non-natives. Fertilizer requirements have not been tested.

Without question, most turfgrasses and landscape plants may require fertilization on most of Florida's sandy, low-fertility soils, because all plants require the presence of essential nutrients for sustainability. It is true that some plants require more 
nutrients than others, but all plants must acquire a minimum amount of $\mathrm{N}, \mathrm{P}$, and $\mathrm{K}$ to survive. In most cases, the most limiting nutrient is $\mathrm{N}$ and it is usually applied in the largest quantity. A small portion of the required $\mathrm{N}$ is supplied through natural rainfall. If clippings are returned, they may supply up to $2 \mathrm{lbs}$ of additional N per 1000 sq ft per year (Sartain, 2004).

Use of reclaimed water may supply an additional quantity of the required $\mathrm{N}$. The quantity of $\mathrm{N}$ supplied by reclaimed water depends on the concentration of $\mathrm{N}$ in the water and the quantity of water used. These three sources may in some cases supply all of the $\mathrm{N}$ needed to sustain the turfgrass. However, in most cases when turfgrasses are grown on Florida's sandy soils, additional fertilizer nutrients will be required to sustain the turfgrass over the long term. In some cases, the turfgrass may survive for a year or so without fertilization, but in the long term the turfgrass may thin and require extensive fertility management in order to bring it back to health.

Phosphorus fertilization on established turfgrass is not as frequently required as $\mathrm{N}$ fertilization. Phosphorus fertilization is most essential during early establishment of the turfgrass because it significantly influences rooting. After establishment, most turfgrasses can survive on very low levels of fertilizer P. Because many of Florida's soils are phosphatic in nature, additional $\mathrm{P}$ may not be required (Liu et al., 2007). A soil test should always be used to determine if $\mathrm{P}$ fertilization is required.

About one-half as much $\mathrm{K}$ as $\mathrm{N}$ is needed for maintenance of a healthy turfgrass. However, in most cases most of the $\mathrm{K}$ requirement of turfgrasses can be met by the returning the clippings (Sartain, 1993). Fortunately, $\mathrm{K}$ is not a pollutant, thus the only negatives to $\mathrm{K}$ fertilization are the depletion of a natural resource, possibly increased soluble salts in the soil, and an added economic expense.

Following planting in the landscape, live oak trees grow without fertilizer, but they grow slightly faster with fertilizer. We also are finding (data not published) that this also holds true in a field nursery, at least in the four-year trial with 1,300 trees we are now conducting.
For centuries, humans have used turfgrasses to enhance their environment and quality of life. Turfgrasses have many benefits that can be separated into functional, aesthetic, and recreational components:

- Functional benefits include soil erosion control, dust stabilization, enhanced ground water recharge and improved surface water quality, improved entrapment and decomposition of chemical pollutants, soil improvement and restoration, heat dissipation and temperature moderation, noise abatement, glare reduction, and sequestration of carbon dioxide.

- Aesthetic benefits are a positive therapeutic benefit that improves mental health and productivity, contributes to social harmony and stability, and generally improves quality of life, especially in densely populated areas.

- Recreational benefits are a relatively low-cost, safe surface that reduces injuries when compared to non-turf areas. Additionally, the upkeep and maintenance of lawns provide exercise and a diversion beneficial to mental health.

These benefits were identified by Beard and Green (1994).

\section{Is there scientific evidence that landscape fertilization is associated with the occurrence of red tide?}

Recent studies have shown that increased nutrient levels are likely linked to the occurrence of red tide but, the source of the nutrients has not been determined. It is important to note, however, that most red tide events are initiated miles away from the shore. These outbreaks then move towards shore with the wind. The red tide-causing organism Karenia brevis does not require large amounts of nutrients to survive. Researchers have suggested that excessive loss of $\mathrm{N}$ from terrestrial landscapes may prolong the duration of red tide events. However, there is no hard science (in any research publication) to support the fact that fertilizer runoff and/or leaching leads to initiation of red tide blooms (Alcock, 2007). Proper application of fertilizers to landscapes cannot be 
overemphasized, so that the environmental value of turfgrasses becomes apparent.

\section{What is the impact of fertilizers and lawn chemicals on red tide?}

Karenia brevis is highly adept at utilizing both organic and inorganic nutrients. The relative importance of different nutrient sources varies over the stage of a bloom and it is possible that the specific combination of nutrient sources that are responsible for a major bloom varies from year to year. Most scientists agree that red tide blooms initiate offshore before being transported inshore by wind and ocean currents and express skepticism that terrestrial nutrients affect the early stages of a bloom. However, when a bloom moves inshore, most acknowledge that runoff can help maintain the life of the bloom or affect its growth. How much of a role these nutrients play remains unclear. Complicating the issue further, coastal nutrients can be categorized as either "natural"- present during even pre-historic times — or anthropogenic — the result of human activities. Distinguishing between the two can be difficult in nature (Alcock, 2007). Proper fertilization is critical!

\section{Do urea-based fertilizers serve as a "food source" for Karenia brevis?}

Nitrogen undergoes several modes of transformation. Any N source could be considered as a food source for Karenia brevis, either directly or indirectly. There have been dozens of theories involving suspected nutrient delivery mechanisms for $K$. brevis. Scientists stress that these mechanisms are not mutually exclusive and that no single source can account for all the nutrients required to sustain a major bloom. Aside from the land-based nutrient sources, there are a number of atmospheric and oceanic sources that are receiving increased attention. Upwellings of deep, nutrient-enriched water along the continental shelf are viewed as playing a potential role in initiation of offshore blooms. A second significant source of nutrients may be trichodesmium, a cyanobacteria found throughout the world's oceans. Trichodesmium can provide significant nutrients to $K$. brevis through the process known as nitrogen fixation. With adequate supplies of iron, trichodesmium can fix $\mathrm{N}$ from the atmosphere and excrete it in a form that can be used by $K$. brevis.

In recent decades, increased desertification in Africa and the resulting transoceanic dust clouds have meant more iron deposits in the Gulf of Mexico. The increases in iron deposits seem to coincide with trichodesmium blooms that are accompanied by red tide. A third significant source of nutrients is rotting fish. Since dead fish often drift to the bloom before floating to the top, a massive fish kill triggered by a bloom could conceivably lead to the dispersal of a large amount of nutrients throughout the water column. It is highly likely that the predominant nutrient source changes over the course of a bloom and it remains unclear whether a particular combination of sources is common to all blooms (Alcock, 2007).

\section{How are irrigation practices and fertilizer use related? Is there a way to link them together in a way to minimize fertilizer leaching or runoff?}

Fertilizer use and irrigation are not directly related in a properly managed landscape. Fertilizer is applied to supply the required nutrients and irrigation is applied to sustain the turgidity of the plants when natural rainfall does not supply enough water. Unfortunately, in many cases irrigation is used in excess, which may result in nutrient leaching (Shaddox \& Sartain, 2000).

One of the downsides of reclaimed water being used as an irrigation source is that in many cases it is viewed as containing "free" nutrients. The municipality may require the use of a certain quantity of water frequently, which may lead to excessive irrigation and leaching of nutrients. As more municipalities begin charging for reclaimed water, a more conservative approach to its use may develop that will reduce excessive irrigation and leaching of applied nutrients. 


\section{What is the Florida Friendly Green Industries BMP Educational Program?}

The Florida-Friendly Green Industries Best Management Practices (BMP) educational program was developed by the Florida Department of Environmental Protection (FDEP), UF/IFAS industry representatives, and others to guide commercial lawn-care and landscape industry professionals in the use of sound horticultural practices. The goal of implementing the BMPs is to reduce potential environmental impact resulting from landscape maintenance. BMP practices use horticultural and environmental science-based information. UF/IFAS Extension offices and other venues statewide deliver the program via trainings to Green Industry workers. Many cities and counties have enacted local fertilizer ordinances which require lawn-care professionals to become certified in the BMPs. A written BMP Manual is available at the trainings or by contacting your county Extension office.

\section{Who should become BMP certified-every worker, or just supervisors and foremen?}

BMP training is recommended for all Florida landscape industry workers, including installers, designers, mowers and pruners, fertilizer and pesticide operators, managers, and sales representatives. Individuals who successfully finish the training will receive a Certificate of Completion.

Those who are unable to pass the written test due to literacy issues should still attend a training to improve their knowledge about environmental protection. The course and the written test are compliant with the Americans with Disabilities Act and are offered in both English and Spanish.

\section{Is a BMP training from one county good in another county?}

The BMP training program is a state educational program. There are strong incentives, both regulatory and financial, for local governments to accept the state program if they require training, but under their constitutional rights of Home Rule, it is not required.

\section{Is a BMP Certificate of Completion good forever, or are updates required? If updates are required, how often?}

Training updates will be provided on a regular basis. At this time, individuals should plan to obtain additional training every one to three years if training is mandatory in their area, depending on their local ordinances. Instructors are required to be up-to-date at all times and are required to attend refresher courses every two years.

\section{References}

Alcock, F. (2007). An assessment of Florida red tide: Causes, consequences and management strategies (Technical Report \#1190). Sarasota, FL: Mote Marine Laboratory.

Beard, J. B., \& Green R. L. (1994). The role of turfgrasses in environmental protection and their benefits to humans. Journal of Environmental Quality, 23, 452-460.

Brown, E. A., \& Sartain, J. B. (2003). Differential nitrate leaching and mass balance of 15 N-labeled nitrogen sources. Proceedings of the Soil Crop Science Society of Florida, 62, 92.

Dudeck, A. E., Sartain, J. B., \& Peacock C.H. (1982). Lawn fertilization trials for North Florida. Proceedings of the Florida State Horticultural Society, 95, 272-275.

Erickson, J. E., Volin, J. C., Cisar, J. L., \& Snyder, G. H. (1999). A facility for documenting the effect of urban landscape type on fertilizer nitrogen runoff. Proceedings of the Florida State Horticultural Society, 112, 266-269.

Erickson, J. E., Cisar, J. L., Volin, J. C., \& Snyder, G. H. (2001). Comparing nitrogen runoff and leaching between newly established St. Augustinegrass turf and an alternative residential landscape. Crop Science, 41, 1889-1895. 
Harivandi, M. A. (1982). The use of effluent water for turfgrass irrigation. California Turfgrass Culture, 32(3-4), 1-4.

Havens, J. (2004). A stable isotopic examination of particulate organic matter during Karenis brevis booms on the West Florida shelf: Hints at nitrogen sources in oligotrophic waters. Unpublished masters thesis, University of South Florida.

Koop, K. L., \& Guillard, K. (2002). Clipping management and nitrogen fertilization of turfgrass: Growth, nitrogen utilization, and quality. Crop Science, 42, 1225-1231.

Liu, M., Sartain, J. B., Trenholm, L. E., \& Harris, W. G. (in press). Comparison of soil test $\mathrm{P}$ procedures for St. Augustinegrass. Communication in Soil Science and Plant Analysis.

Liu, M., Sartain, J. B., Trenholm, L. E., \& Miller, G. L. (2008). Phosphorus requirements of St. Augustinegrass grown in sandy soils. Crop Science, 48, 1178-1186.

Liu, M., Sartain, J. B., Trenholm, L. E., Miller, G. L., \& Nkedi-Kizza, P. (2006). St. Augustine phosphorus requirement using hydroponic culture. Proceedings of the Soil Crop Science Society of Florida, 65, 15-20.

Park, D. M. (2006). Nitrogen leaching and St. Augustine turf response to lawn maintenance strategies. Unpublished doctoral dissertation, University of Florida.

Rosen, C., Horgan, B., Hollman, A., McNearney, M., \& Bierman, P. (2008). Research update:

Phosphorus runoff from turfgrass. Minneapolis, MN: University of Minnesota.

Ruple, G. J., Sarkar, D., Sartain, J. B., \& OConnor, G. A. (1999). Reuse of Carlton reject water. I. Effects on bermudagrass yield. Proceedings of the Soil Crop Science Society of Florida, 58, 31-37.

Sartain, J. B. (1993). Interrelationships among turfgrasses, clipping recycling, thatch and applied calcium, magnesium and potassium. Agronomy Journal, 85, 40-43.
Sartain, J. B. (1996). The fate of applied turfgrass nutrients. Grounds Maintenance, 31(3), 26-30.

Sartain, J. B. (2002). Tifway bermudagrass response to potassium fertilization. Crop Science, 42, 507-512.

Sartain, J. B. (2004). Returning clippings reduces fertilizer losses. Grounds Maintenance, 39(4), 12-23. Mowing turfgrass at the correct height can increase root growth and help to minimize leaching.

Sartain, J. B. (2007, May 1). General recommendations for fertilization of turfgrasses on Florida soils. University of Florida/IFAS Extension EDIS, Publication \#SL21. Retrieved November 2, 2008, from http://edis.ifas.ufl.edu/LH014.

Sartain, J. B. (in press). Comparative influence of $\mathrm{N}$ source on leaching of $\mathrm{N}$ and St. Augustinegrass quality, growth and N uptake. Proceedings of the Soil Crop Science Society of Florida.

Sartain, J. B. (in review). Soil and tissue testing and interpretation for Florida turfgrasses. University of Florida/IFAS Extension EDIS, Publication \#SL181.

Sartain, J. B., \& Gooding, H. D. (2000). Reducing nitrate leaching during green grow-in. Golf Course Management, 2, 70-73.

Sartain, J. B., \& Kruse J. K. (2001, April 1). Selected fertilizers used in turfgrass fertilization. University of Florida/IFAS Extension EDIS, Publication \#CIR1262. Retrieved November 2, 2008, from http://edis.ifas.ufl.edu/SS318.

Sartain, J. B., \& Volk, B. G. (1984). Influence of selected white-rot fungi and topdressing on the composition and thatch components of four turfgrasses. Agronomy Journal, 76, 359-362.

Shaddox, T. W., \& Sartain, J. B. (2000, June). Fate of nitrogen during grow-in of a golf course fairway under different nitrogen management practices. Paper presented at the 2000 Soil and Crop Science Society of Florida Meeting, Tallahassee, FL. 
Trenholm, L. E., \& Unruh, J. B. (2005).

Warm-season turfgrass response to fertilizer rates and sources. Journal of Plant Nutrition, 28, 991-999.

Trenholm, L. E., \& Unruh, J. B. (2007). St. Augustinegrass fertilizer trials. Journal of Plant Nutrition, 30(3), 453-461.

Volk, G. M. (1956). Efficiency of various nitrogen sources for pasture grasses in large lysimeters of Lakeland fine sand. Proceedings of the Soil Science Society of America, 20(1), 41-45.

Volk, G. M. (1961). Gaseous loss of ammonia from surface applied nitrogenous fertilizers. Journal of Agricultural and Food Chemistry, 9(4), 280-283.

Questions should be directed to Terril A. Nell (tanell@ufl.edu), Director, Center for Landscape Conservation and Ecology. 